\title{
PELATIHAN SALON KECANTIKAN KHUSUS PEMASANGAN BULU MATA DENGAN KONSENTRASI PADA PENGELOLAAN KEWIRAUSAHAAN PEMULA GUNA MENIMBULKAN MINAT KEWIRAUSAHAAN BAGI SANTRI PADA RUMAH YATIM DAN DUAFA AL- AMIEN
}

\author{
Budhi Prabowo, Krisnaldy, Moh. Jazuli, Kenny Astria \\ Dosen Ekonomi Fakultas Ekonomi Universitas Pamulang \\ Email : dosen02034@unpam.ac.id, dosen01890@unpam.ac.id \\ , dosen01680@unpam.ac.id, dosen01899@unpam.ac.id,
}

\begin{abstract}
ABSTRAK
Pengabdian ini berjudul pelatihan salon kecantikan Khusus Pemasangan Bul Mata dengan Konsentrasi pada pengelolaan Kewirausahaan Pemula Guna Menimbulkan Minat kewirausahaan Bagi santri

Tujuan pengabdian ini adalah untuk memberikan pelatihan salon kecantikan Khusus Pemasangan Bul Mata dengan Konsentrasi pada pengelolaan Kewirausahaan Pemula Guna Menimbulkan Minat kewirausahaan Bagi santri Metode pelaksanaan pengabdian ini dilakukan dalam beberapa kegiatan yaitu tahap survei yaitu sosialisasi dilakukan dengan menyusun berbagai hal yang akan disampaikan pada saat kegiatan pengabdian yang akan dilakukan yang meliputi: penyusunan materi yang akan diberikan, penyusunan jadwal pemberian materi, pembagian tugas tim pengabdian dan survei ke lokasi pengabdian. Tahap sosialisasi yaitu sebelum kegiatan pengabdian dilaksanakan terlebih dahulu dilakukan tahap sosialisasi yaitu melakukan silaturahmi dengan perwakilan lurah, menyampaikan maksud dan tujuan pengabdian ini. Pada tahap ini juga dilakukan jalinan kerjasama dan menentukan jadwal kegiatan pengabdian. Tim pelaksana kegiatan pengabdian pada masyarakat adalah dosen Fakultas Ekonomi jurusan manajemen sebanyak 4 orang. Tim pengabdian memberikan materi tentang pelatihan salon kecantikan Khusus Pemasangan Bul Mata dengan Konsentrasi pada pengelolaan Kewirausahaan Pemula Guna Menimbulkan Minat kewirausahaan Bagi santri

Kesimpulan dari pengabdian ini adalah Peserta sangat antusias terhadap pelakasanaan kegiatan ini sehingga membangkitkan keinginan untk berwirausaha. Harapan kami dengan pengabdian ini dapat membuka wawasan masyarakat yang diperoleh adalah bertambahnya keilmuan bagi para Para Masyarakat dan Ilmu yang diperoleh pada Pengabdian Masyarakat kali ini diharapkan mampu memberikan semangat baru bagi kita dalam menyampaikan materi dan motivasi serta berkontribusi bagi generasi muda, baik dilingkungan sekolah, kampus dan keluarga
\end{abstract}

\section{Kata Kunci: Pelatihan, Pengelolaan, Kewirausahaa}

\section{ABSTRAC}

This service is entitled training of a beauty salon specifically for eye bulb installation with a concentration on managing entrepreneurship for beginners in order to generateentrepreneurial interest for students.

The purpose of this service is to provide training for beauty salons specifically for eyeball fitting with a concentration on entrepreneurial management for beginners in order to generate entrepreneurial interest for students. which will be carried out which includes: preparation of

the material to be given, preparation of a schedule for the provision of materials, division of the task of the service team and a survey to the service location. The socialization stage, namely 


\section{Loyalitas Kreativitas Aldi Masyarakat Kreatif \\ Program Studi Ekonomi Manajemen Universitas Pamulang Jurnal LOKABMAS Kreatif Vol.02,No.02.Juli 2021 Hal.82-88 \\ Email:jurnalkreatif.manajemen@gmail.com}

P-ISSN 2722-2101, E-ISSN 2722-4201

before the service activity is carried out, the socialization stage is carried out first, namely conducting a gathering with representatives of the village head, conveying the aims and objectives of this service. At this stage, a collaboration is also carried out and determines a schedule of service activities. The team for implementing community service activities consists of 4 lecturers at the Faculty of Economics, majoring in management. The community service team provides material about beauty salon training specifically for eye bulb installation with a concentration on managing entrepreneurship for beginners in order to generate entrepreneurial interest for students.

The conclusion of this service is that the participants are very enthusiastic about the implementation of this activity so that it arouses the desire for entrepreneurship. Our hope with this dedication can open up the insights of the community obtained is the increase in knowledge for the Community and the knowledge obtained at this Community Service is expected to be able to provide new enthusiasm for us in conveying material and motivation and contributing to the younger generation, both in the school environment and on campus. and family

Keywords: Training, Management, Entrepreneurship

\section{PENDAHULUAN}

\section{Landasan Teori}

Kewirausahaan (entrepreneurship) adalah kemampuan kreatif dan inovatif yang dijadikan dasar, kiat, dan sumber daya untuk mencari peluang menuju sukses. Sesuatu yang baru dan berbeda adalah nilai tambah barang dan jasa yangmenjadi sumber keuanggulan untuk dijadikan peluang. Jadi, kewirausahaanmerupakan suatu kemampuan dalam menciptakan nilai tambah di pasar melalui proses pengelolaan sumber daya dengan caracara baru dan berbeda.

Di Indonesia, kewirausahaan dipelajari baru terbatas pada beberapa sekolah atau perguruan tinggi tertentu saja. Sejalan dengan perkembangan dan tantangan seperti adany 1 . krisis ekonomi, pemahaman kewirausahaa baik melalui pendidikan formal maupu: pelatihan-pelatihan di segala lapisa 2. masyarakat kewirausahaan menjac berkembang.

Orang yang melakukan kegiatan kewirausahaan disebut wirausahawan. Muncu3. pertanyaan mengapa seorang wirausahawa (entrepreneur) mempunyai cara berpikir yan. berbeda dari manusia pada umumnya. Mereka mempunyai motivasi, panggilan jiwa, persepsi dan emosi yang sangat terkait dengan nilai nilai, sikap dan perilaku sebagai manusia unggul. Pada makalah ini dijelaskan tentang pengertian, hakekat, ciri-ciri dan karakteristik dan peran kewirausahaan dalam perekonomian nasional. Kewirausahaan berasal dari kata wira dan usaha. Wira berarti :pejuang, pahlawan, manusia unggul, teladan, berbudi luhur, gagah beranidan berwatak agung. Usaha, berarti perbuatan amal, bekerja, berbuatsesuatu. Jadi wirausaha adalah pejuang atau pahlawan yang berbuatsesuatu. Ini baru dari segi etimologi (asal usul kata). Menurut KamusBesar Bahasa Indonesia, wirausaha adalah orang yang pandai atauberbakat mengenali produk baru, menentukan cara produksi baru,menyusun operasi untuk mengadakan produk baru, mengatur permodalanoperasinya serta memasarkannya.Dalam lampiran Keputusan Menteri Koperasi dan PembinaanPengusahan Kecil Nomor 961/KEP/M/XI/1995, dicantumkan bahwa:

Wirausaha adalah orang yang mempunyai semangat, sikap, perilakudan kemampuan kewirausahaan.

Kewirausahaan adalah semangat, sikap, perilaku dan kemampuanseseorang dalam menangani usaha atau kegiatan yang

mengarahpada upaya mencari,
menciptakan serta menerapkan cara
kerja,teknologi dan produk baru
Jadi wirausaha itu mengarah kepada orang yang melakukanusaha/kegiatan sendiri dengan segala kemampuan yang dimilikinya.Sedangkan kewirausahaan menunjuk kepada sikap mental yang dimilikiseorang wirausaha dalam melaksanakan usaha/kegiatan.Kewirausahaan 


\section{Loyalitas Kreativitas \\ P-ISSN 2722-2101, E-ISSN 2722-4201 \\ Aldi Masyarakat Kreatif \\ Program Studi Ekonomi Manajemen Universitas Pamulang \\ Jurnal LOKABMAS Kreatif Vol.02,No.02.Juli 2021 Hal.82-88 \\ Email:jurnalkreatif.manajemen@gmail.com}

dilihat dari

sumber daya yang ada di dalamnyaadalah seseorang yang membawa sumber daya berupa tenaga kerja,material, dan asset lainnya pada suatu kombinasi yang menambahkannilai yang lebih besar daripada sebelumnya dan juga dilekatkan padaoran 2 . yang membawa perubahan, inovasi, da: aturan baru.Kewirausahaan dalam arti prose yang dinamis adalahkewirausahaa merupakan sebuah proses mengkreasika 3 . denganmenambahkan nilai sesuatu yan. dicapai melalui usaha keras dan waktuyan, tepat dengan memperkirakan dan pendukung, fisik, dan resikosocial, dan aka 4. menerima reward yang berupa keuangan da: kepuasanserta kemandirian personal.Melalu pengertian tersebut terdapat empat hal yang dimiliki olehseorang wirausahawan yakni:

1. Proses berkreasi yakni mengkreasikan sesuatu yang baru denganmenambahkan nilainya. Pertambahan nilai ini tidak hanya diakui olehwirausahawan semata namun jug ${ }_{1}$. audiens yang akan menggunakanhasil kreas tersebut.

2. Komitmen yang tinggi terhada penggunaan waktu dan usaha yangdiberikar Semakin besar fokus dan perhatian yan 2 . diberikan dalam usaha ini maka aka mendukung proses kreasi yang akan timbu dalamkewirausahaan.

3. Memperkirakan resiko yang mungki 3 . timbul. Dalam hal ini resiko yangmungki terjadi berkisar pada resiko keuangan, fisi. dan resiko social.

4. Memperoleh reward. Dalam hal ir reward yang terpenting adalahindependens atau kebebasan yang diikuti dengan kepuasa pribadi.Sedangkan reward berupa uang biasanya dianggap sebagai suatubentukderajat kesuksesan usahanya.

\section{B.}

\section{Tujuan}

Kewirausahaan

Bahan ajar mata diklat Kewirausahaan dapat diajarkan dan dikembangkandi Sekolahsekolah Dasar, Sekolah Menengah, Perguruan Tinggi, dan diberbagai kursus bisnis. Di dalam pelajaran Kewirausahaan, para siswadiajari dan ditanamkan sikap-sikap perilaku untuk membuka bisnis, agar mereka menjadi seorang wirausaha yang berbakat. Agar lebih jelas, dibawah ini diuraikan tujuan dari Kewirausahaan, sebagai berikut:

1. Meningkatkan jumlah para wirausaha yang berkualitas.

2. Mewujudkan kemampuan dan kemantapan para wirausaha untuk menghasilkan kemajuan dan kesejahteraan masyarakat.

3. Membudayakan semangat sikap, perilaku, dan kemampuankewirausahaan di kalangan pelajar dan masyarakat yang mampu,handal, dan unggul.

Menumbuhkembangkan kesadaran dan'orientasi Kewirausahaanyang tangguh dan kuat terhadap para siswa dan masyarakat.

\section{Manfaat Kewirausahaan}

Kewirausahaan memiliki 4 manfaat sosial, yaitu:

Memperkuat pertumbuhan ekonomi : menyediakan pekerjaan barudalam ekonomi. Ekonomi saat ini adalah tanah yang subur bagiwirausahawan misalnya : permintaan pelayanan sektor jasa meledak

Meningkatkan produktivitas : kemampuan untuk menghasilkan lebihbanyak barang dan jasa dengan TK dan input lain yang lebih sedikit.

Menciptakan teknologi, produk dan jasa baru: komputer digital,mesinfotokopi, laser, power steering.

Mengubah dan meremajakan persaingan pasar : pasar internasionalmenyediakan peluang kewirausahaan.

\section{KEBERHASILAN DAN KEGAGALAN WIRAUSAHAWAN}

\section{A. Keberhasilan Kewirausahaan}

\section{a. Kerjakeras.}

Dalam menjalankan usaha kita perlu menyadari bahwa setiap orang yang menekuni bidang usaha, usaha apapun itu, dituntut untuk memiliki pemikiran untuk selalu bekerja keras dan tekun. 


\section{Loyalitas Kreativitas \\ P-ISSN 2722-2101, E-ISSN 2722-4201 \\ Program Studi Ekonomi Manajemen Universitas Pamulang \\ Jurnal LOKABMAS Kreatif Vol.02,No.02.Juli 2021 Hal.82-88 \\ Aldi Masyarakat Kreatif \\ Email:jurnalkreatif.manajemen@gmail.com}

b. Kerja sama dengan orang lain. Sebagai makhluk sosial, yang mau tidak mau kita musti bergantung kepada orang lain, maka dari itu semestinyalah kita belajar bergaul dan membawa diri pada orang lain.

\section{c. Penampilan yang baik.}

Penampilan adalah cerminan kebersihan hati dan perilaku seseorang, oleh karena itu, untuk menunjang usaha yang kita lakukan maka penampilan juga sangat berperan.

d. Yakin,

keyakinan.

Segala sesuatu yang dilakukan wujudkan dalam diri kita bahwa kita bisa.

\section{e. Pandai membuat keputusan.}

f. Mau menambah pengetahuan. Seorang wirausahawan dituntut untuk selalu belajar dari sekelilingnya, lingkungan sekitarnya dan dari produk-produk yang dibuat.

g. Pandai

berkomunikasi.

Belajarlah mengeluarkan kalimat yang baik (sesuai).

\section{B. Kegagalan}

Kewirausahaan

a. Kurangnya dana untuk modal. Tidak semua kegagalan disebabkan karena modal yang tidak ada, akan tetapi sebagian besar kegagalan itu ada karena kurangnya dana.

b. Kurangnya pengalaman dalam bidang bisnis.

Berikan suatu jabatan kepada ahlinya, dengan kata lain tempatkan sesuatu pada tempatnya.

c. Tidak adanya perencanaan yang tepat dan matang.

Dalam berwirausaha, merencanakan sesuatu, atau menyusun sesuatu perlu disiapkan sebelumnya.

d. Tidak cocoknya minat terhadap bidang usaha yang sedang digeluti (diteliti). Terkait dengan penjelasan point $\mathrm{b}$ diatas, yaitu menempatkan sesuatu pada tempatnya, termasuk tempatkan minat dan bakat dimana orang itu berminat dan berbakat agar usaha atau pekerjaan yang dilakukan menjadi sahabat dan dapat ditekuni dengan baik.

\section{Sebab - sebab Kegagalan dalam Menjalankan Usah}

a. Kurang ulet dan cepat putus asa, sedangkan kita harus dituntut untuk rajin, tekun, sabar, dan jangan putus asa.

b. Kurang tekun dan teliti.
Pelatihan
Kewirausahaan
Pemuda
diselenggarakan melalui beberapa langkah kegiatan sebagai berikut :

1. Mengidentifikasi Kebutuhan Pelatihan Sebelum pelatihan diselenggarakan, dinas pengelola program peningkatan partisipasi pemuda perlu melakukan identifikasi terhadap kebutuhan dan potensi-potensi penyelenggaraan pelatihan. Identifikasi kebutuhan pelatihan dimaksudkan untuk mencari dan menetapkan jenis-jenis kemampuan wirausaha yang harus dimiliki pemuda peserta pelatihan, yang selanjutnya diterjemahkan kedalam materi-materi pelatihan. Secara umum perkiraan materi pelatihan kewirausahaan pemuda sesuai penjenjangannya dijelaskan pada bagian terdahulu. Fungsi identifikasi dalam hal ini adalah mengklarifikasi, memverifikasi dan mendetailkan materi-materi tersebut. Identifikasi secara khusus dan utama ditujukan untuk menetapkan jenis komoditas usaha yang menguntungkan dilihat dari berbagai aspek, terutama aspek pengembangan kepemudaan dan ekonomi masyarakat desa. Oleh karena itu, identifikasi perlu diawali dengan menelaah rencana pengembangan perekonomian daerah yang tercakup dalam dokumen rencana strategis pembangunan daerah. Dokumen tersebut menggambarkan paling tidak tentang klusterkluster pengembangan ekonomi produktif berikut jenis-jenis komoditasnya. Setelah jelas lokasi pengembangan ekonomi produktif yang ditetapkan, maka selanjutnya Dinas perlu merancang program Sarjana Penggerak Pembangunan di Perdesaan (SP-3) ditugaskan pada lokasi tersebut. Juga program-program lainnya yang memiliki mainstream pengembangan kewirausahaan 2. Menyusun Desain Pelatihan Desain pelatihan merupakan bagian dari gran desain (Grand Design) pengembangan kewirausahaan pemuda yang dijabarkan dari 


\section{Loyalitas Kreativitas \\ P-ISSN 2722-2101, E-ISSN 2722-4201 \\ Aldi Masyarakat Kreatil \\ Program Studi Ekonomi Manajemen Universitas Pamulang \\ Jurnal LOKABMAS Kreatif Vol.02,No.02.Juli 2021 Hal.82-88 \\ Email:jurnalkreatif.manajemen@gmail.com}

pengembangan ekonomi daerah. Oleh karenanya, penyusunan desain pelatihan perlu memperhatikan tujuan dan target yang terdapat pada gran desain.

Desain pelatihan mencakup gagasan dan rencana kerja pelatihan yang berorientasi pada pengembangan kewirausahaan pemuda. Dalam konteks ini, pelatihan diartikan bukan hanya pembelajaran dalam kelas, tetapi termasuk juga pembimbingan dan pendampingan di alam kerja/lapangan. Juga mencakup tiga tahap (level) pelatihan seperti tersebut di

atas.

Desain pelatihan paling tidak menguraikan aspek-aspek sebagai berikut : a. Latar belakang, yang menguraikan data dan alasan mengapa diperlukan pelatihan kewirausahaan pemuda, termasuk di dalamnya alasan tentang pengembangan ekonomi produktif melalui budi daya komoditas tertentu. b. Dasar pelaksanaan; menguraikan dasar yuridis pelaksanaan pelatihan, meliputi peraturan-peraturan daerah, keputusankeputusan pejabat daerah. c. Tujuan pelatihan; menjelaskan tentang kompetensi lulusan/peserta pelatihan, baik berkenaan dengan penguasaan dan pembiasaan sikap/mental kewirausahaan, pengelolaan usaha maupun teknis usaha. d. Tujuan pelatihan dirumuskan sesuai penjenjangan pelatihan kewirausahaan pemuda.

e. Materi pelatihan; menguraikan tentang materi atau substansi yang akan dilatihkan kepada peserta pelatihan, sehingga mereka menguasai kompetensi-kompetensi lulusan yang telah dirancang dalam tujuan pelatihan. Materi pelatihan berkisar pada kebijakankebijakan pemerintah tentang kewirausahaan pemuda, teori dan aplikasi/ pengalaman wirausaha dan teknik atau kiat-kiat sukses berwirausaha.

f. Materi pelatihan disusun dalam sesi-sesi yang sikuentif dan sistematis dengan alokasi waktu tiap sesi 45 sampai dengan 90 menit. g. Metode dan teknik pelatihan; menguraikan tentang metode pelatihan yang akan digunakan berikut teknik-teknik pembelajarannya. Metode pelatihan yang disarankan adalah pembelajaran di kelas, pembiasaan dan pelatihan di lapangan melalui belajar dari pengalaman dan pemecahan masalah.

h. Pemilihan metode dan teknik pembelajaran perlu memperhatikan penjenjangan pelatihan kewirausahaan pemuda, agar proses pelatihan menjadi segar dan menyenangkan bagi peserta.

i. Sarana dan prasarana pelatihan; menguraikan tentang gedung tempat latihan dan alat-alat, perlengkapan serta media-media belajar yang akan digunakan dalam pelatihan. Untuk sarana perlu mempertimbangkan setiap peserta pelatihan menggunakannya dengan leluasa dan aman, terutaama pada penetapan alat-alat praktik. j. Pelatih dan Panitia; menguraikan tentang kualifikasi dan tugas pelatih serta panitia. Pelatih dipilih dari lembaga atau individu yang kompeten di bidangnya serta memiliki jaringan yang kuat dan luas tentang permodalan, pemasaran dan bantuan teknis usaha.

k. Peserta pelatihan; menguraikan tentang profil, kualitikasi dan tugas peserta pelatihan. Juga mencakup jumlah dan asal daerah/ lembaga peserta. Dirancang pula pengelompokkan peserta dalam pembelajaran dan penerapan hasil belajarnya di lapangan. 1. Waktu dan Tempat pelatihan; menjelaskan tentang lokasi pelatihan berikut nama tempat dan alamatnya, lama waktu pelatihan, mulai tanggal berapa, bulan apa sampai dengan tanggal dan bulan berapa. m. Prosedur dan jadwal pelatihan; mendeskripsikan tentang langkah-langkah sekwentif yang akan dilakukan, mulai tahap perencanaan, pelaksanaan dan penilaian serta tindak lanjut. Tahap-tahap kegiatan tersebut diuraikan dalam jadwal kerja pelatihan. Jadwal kerja menginformasikan tentang kegiatan, waktu, tempat dan petugas yang melaksanakan kegiatan tersebut..

\section{BIAYA}

Sumber biaya berasal dari anggaran pemerintah pusat dan daerah serta anggaran swasta yang tidak mengikat. Jumlahnya disesuaikan dengan standar harga satuan setempat. Pos-pos pembiayaan dan besarannya mengacu pada peraturan dan petunjuk teknis yang dikeluarkan pemerintah. I. TINDAK

LANJUT Setelah laporan selesai disusun, maka 


\section{Loyalitas Kreativitas \\ P-ISSN 2722-2101, E-ISSN 2722-4201 \\ Program Studi Ekonomi Manajemen Universitas Pamulang \\ Jurnal LOKABMAS Kreatif Vol.02,No.02.Juli 2021 Hal.82-88 \\ Aldi Masyarakat Kreatif \\ Email:jurnalkreatif.manajemen@gmail.com}

kegiatan

berikutnya adalah merencanakan dan melaksanakan tindak lanjut pelatihan. Bentuk kegiatannya minimal mencakup 4 (empat) kegiatan sebagai berikut. 1. Evaluasi dampak dari pelatihan. Kegiatan ini dilakukan minimal 4 (empat) bulan setelah pelatihan dilaksanakan, bertujuan untuk mengukur dan menilai apakah pelatihan yang telah dilakukan mempunyai dampak terhadap penguasaan kewirausahaan pemuda dan terhadap pendapatan pemuda dan masyarakat sekitarnya. Dampak ini bisa bersifat negatif dan positif. Evaluasi dampak dilakukan oleh tim independen untuk menjamin obyektivitas. 2. Penguatan implementasi hasil pelatihan berupa bimbingan teknis. Sejak penilaian akhir pelatihan, tingkat penguasaan materi pelatihan oleh masingmasing peserta telah diketahui. Bahkan setelah dilakukan evaluasi dampak makin jelas siapa-siapa yang harus dibina lebih lanjut pasca pelatihan dan siapa-siapa yang harus diberikan perlakuan khusus. Oleh karena itu, bimbingan teknis kepada setiap peserta menjadi mutlak dilakukan, agar terjamin proses implementasi hasil peltihan oleh peserta, yang pada akhirnya terjamin pula terciptanya wirausahawan-wirausahawan yang tangguh.

3. Pemberian bantuan modal Salah satu pembinaan pasca pelatihan kewirausahaan adalah pemberian bantuan modal, karena wirausahawan pemula sangat membutuhkannya. Oleh karena itu, skema pembantuan modal perlu dirancang sebagai bagian tidak terpisahkan dalam sistem penyelenggaraan pelatihan kewirausahaan pemuda.

4. Penguatan jaringan pemasaran Hal penting lainnya untuk pembinaan paska pelatihan terhadap alumnus pelatihan kewirausahaan pemuda adalah menciptakan iklim kondusif bagi penguatan jaringan pemasaran yang lebih luas yang dilakukan oleh alumnus.

\section{METODE PELAKSANAAN}

Metodepelaksanaan pengabdian ini dilakukan dalam beberapa kegiatan yaitu tahap survei yaitu sosialisasi dilakukan dengan menyusun berbagai hal yang akan disampaikan pada saat kegiatan pengabdian yang akan dilakukan yang meliputi: penyusunan materi yang akan diberikan, penyusunan jadwal pemberian materi, pembagian tugas tim pengabdian dan survei ke lokasi pengabdian. Tahap sosialisasi yaitu sebelum kegiatan pengabdian dilaksanakan terlebih dahulu dilakukan tahap sosialisasi yaitu melakukan silaturahmi dengan ketua yayasan, menyampaikan maksud dan tujuan pengabdian ini. Pada tahap ini juga dilakukan jalinan kerjasama dan menentukan jadwal kegiatan pengabdian. Tim pelaksana kegiatan pengabdian pada masyarakat adalah dosen Fakultas Ekonomi jurusan manajemen sebanyak 5 orang. Tim pengabdian memberikan materi kepada Yayasan Al Amien Ciater Serpong

\section{HASIL DAN PEMBAHASAN}

Pengabdian Masyarakat (LPPM) Universitas Pamulang yang dilakukan oleh dosen-dosen program studi Manajemen telah berjalan dengan lancar dan mendapat sambutan hangat dari tempat pelaksanaan kegiatan ini

Harapan kami dengan pengabdian ini dapat membuka wawasan masyarakat yang diperoleh adalah bertambahnya keilmuan bagi para Para Masyarakat dan Ilmu yang diperoleh pada Pengabdian Masyarakat kali ini diharapkan mampu memberikan semangat baru bagi kita dalam menyampaikan materi dan motivasi serta berkontribusi bagi generasi muda, baik dilingkungan sekolah, kampus dan keluarga.

\section{KESIMPULAN DAN SARAN Kesimpulan}

Peserta memahami dan antusias tingi dalam mengikuti pelatihan kewirausahaan ini dan semakin yakin memulai usaha.

\section{Saran}

Setelah pengabdian ini diharapkan peserta dapat memiliki hidup yang lebih sehat secara rohani dan membangun kewirausahaan yang lebih baik serta mengajak teman/peserta lainnya untuk ikut menjadi wirausaha yang sukses dan baik. Tim pengabdian agar terus 


\section{P-ISSN 2722-2101, E-ISSN 2722-4201 \\ Loyalitas Kreativitas \\ Program Studi Ekonomi Manajemen Universitas Pamulang Jurnal LOKABMAS Kreatif Vol.02,No.02.Juli 2021 Hal.82-88 \\ Aledi Masyarakat Kreatif \\ Email:jurnalkreatif.manajemen@gmail.com}

melakukan kegiatan-kegiatan serupa secara berkesinambungan di masa yang akan datang

\section{DAFTAR PUSTAKA}

Arikunto, Suharsimi. 2008. DasarDasar Evaluasi Pembelajaran. Jakarta: Bumi Aksara. 308 hlmn.

Hulasoh, E., Syamsuddin, R. A., Praditya, A., Lisdawati, \& Supardi. (2020). Pengaruh Gadget Terhadap Prestasi Belajar Remaja Di Era Milenial Pada Lembaga Bimbingan Belajar Daarul 'Uluum Petukangan Utara, Pesanggrahan, Jakarta Selatan. ABDIMAS

Krisnaldy, 2019, Pengembangan Minat Wirausaha UMKM , Jakarta Selatan

Kartini Kartono, 2008, Pemimpin dan kepemimpinan. Jakarta: Raja Grafindo Persada

Pasaribu, V. L. D., Agrasadya, A., Shabrina, N., \& Krisnaldy, K. (2020). Menjadi Enterpreneur Muda Yang Memiliki Jiwa Leadership Untuk Menghadapi Masa Depan. Abdi Laksana: Jurnal Pengabdian Masyarakat, 1(1).

Pasaribu, V. L. D., Susanti, F., \& Hartuti, E. T. K. (2019). Memotivasi Siswa dan Siswi SMK Letris Indonesia di Dalam Menentukan Pilihan Untuk Melanjutkan Pendidikan Atau Bekerja Setelah Lulus Sekolah. Jurnal Pengabdian Dharma Laksana, 1(2), 161-172.

Pasaribu, V. L. D., Sulaiman, S., Sutiman, S., Thaharudin, T., \& Purnomo, B. Y. (2020). Pengenalan Letak Posyandu Terdekat Dikelurahan Pisangan Dengan Manajemen Pemasaran Revolusi 4.0 Untuk Meningkatkan Pengetahuan Masyarakat Letak Dan Fungsi Posyandu Terdekat Pada Kelurahan Pisangan. Dedikasi
Pkm, l(1), 105-110.

Pasaribu, V. L. D., Oktrima, B., Prabowo, B., Arianto, N., \& Haryoko, U. B. (2020). Progam Pendampingan Dan Penyelenggaraan Pendidikan Anak Pada Usia Dini Terhadap Prestasi Belajar Dilingkungan Rt $020 \mathrm{Rw}$ 009. Kel Giri Peni. Kec Wates. Yogyakarta. Jurnal Lokabmas Kreatif, 1(1), 71-75.

Pasaribu, V. L. D., Jannah, M., Fazar, M., Putra, S. P., Monalisa, M., \& Sofa, M. (2021). MENINGKATKAN PRODUKTIVITAS USAHA DIMASA PANDEMI PADA IBU PKK RT 004/003 KELURAHAN SAWAH BARU CIPUTAT, TANGERANG SELATAN. Abdi Laksana: Jurnal Pengabdian Kepada Masyarakat, 2(2), 295-301.

Pasaribu, V. L. D., Yuniati, H. L., Pranata, R., Sembayu, R., Purba, S. M., \& Nurbayani, T. T. A. (2021). MANAJEMEN KEUANGAN UNTUK MENGHADAPI DAN BERTAHAN DI ERA COVID 19. Jurnal Abdimas Tri Dharma Manajemen, 2(2), 12-18.

Pasaribu, V. L. D., Dwiyatni, A., Sabina, C., Ridwan, M., Gunawan, D. D., \& Noviani, B. C. (2021). EVALUASI PENERAPAN 3M DIMASA PANDEMIC COVID 19. Jurnal Abdimas Tri Dharma Manajemen, 2(2), 54-60.

Pasaribu, V. L. D., Syafei, A. N., Farhan, A., Aufaizah, A., Irani, C., \& Firtiayani, S. R. (2021). PENGARUH DISPLIN PROTOKOL KESEHATAN TERHADAP PENCEGAHAN PENULARAN VIRUS COVID19. Jurnal Abdimas Tri Dharma Manajemen, 2(2), 91-98.

Pratama, A., \& Syamsuddin, R. A. (2020). DAMPAK KOMITMEN ORGANISASI ATAS KINERJA KARYAWAN PT BNI KCP PAMULANG. ProBank. 
P-ISSN 2722-2101, E-ISSN 2722-4201

Loyalitas Kreativitas

Aledi Masyarakat Kreatif

Program Studi Ekonomi Manajemen Universitas Pamulang

Jurnal LOKABMAS Kreatif Vol.02,No.02.Juli 2021 Hal.82-88

Email:jurnalkreatif.manajemen@gmail.com

https://doi.or

g/10.36587/probank.v5i2.723

Rahmi Andini Syamsuddin, Lisdawati, \& Agung Tri Putranto. (2020). Evaluation

Performance of Social Organization in Setu District - South Tangerang. Jurnal Ekonomi \& Bisnis JAGADITHA. https://doi.org/10.22225/jj.7.2.2483.123$\underline{127}$

\section{DOKUMENTASI KEGIATAN}
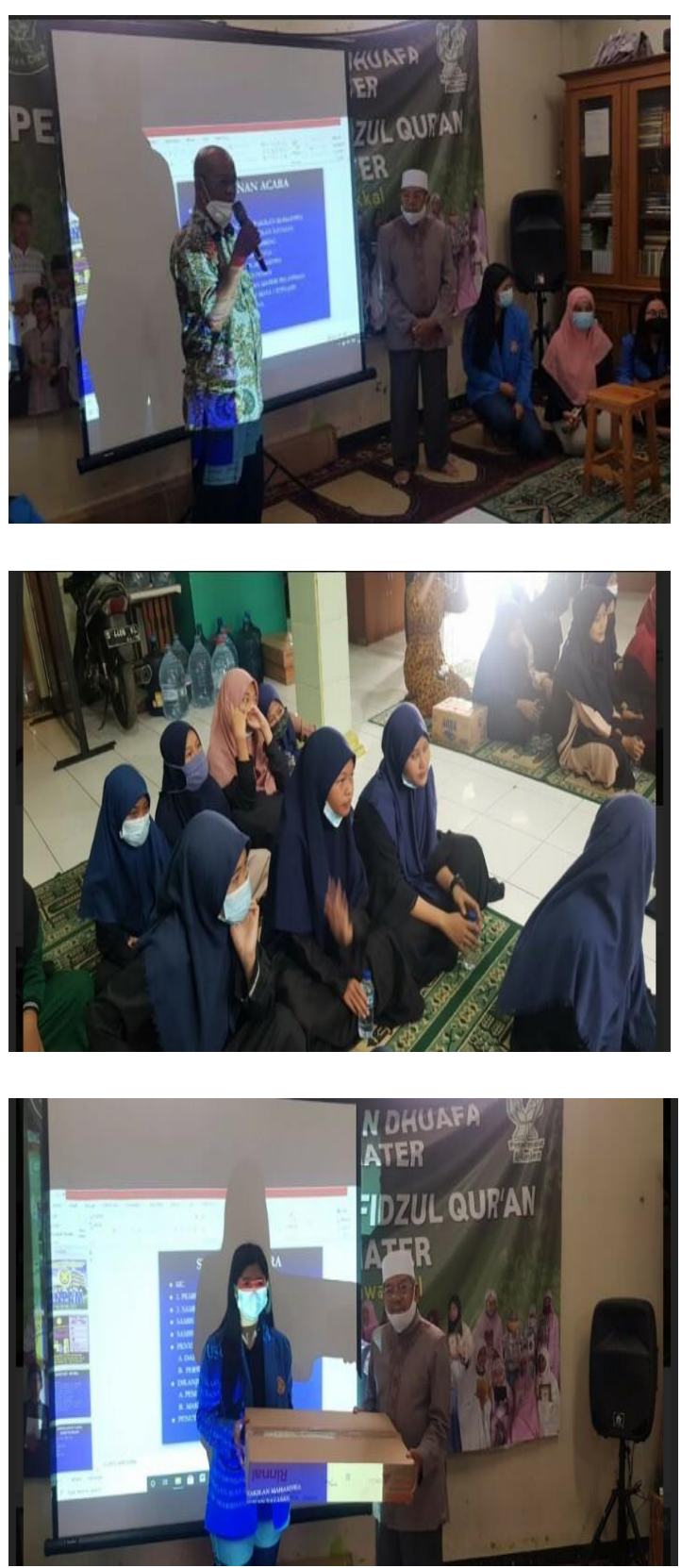